\title{
Realisation or oversight of a constitutional mandate? Corrective rape of black African lesbians in South Africa
}

\author{
Lea Mwambene* \\ Senior lecturer, Faculty of Law, University of the Western Cape, South Africa \\ Maudri Wheal** \\ Candidate Attorney, Bern Rautenbach Attorneys, Cape Town, South Africa
}

\begin{abstract}
Summary
Corrective rape is a form of sexual punishment by men towards lesbians in order to cure them of their sexual orientation. Black African lesbians are victims of corrective rape, particularly those in townships who are seen to challenge patriarchal gender norms. Therefore, discrimination on the basis of gender, race, sex and sexual orientation is called into play. The impact of discrimination is rendered more serious and their vulnerability increased by the fact that the victims are also seen as a threat to patriarchy and hetero-normativity which demarcate women's bodies as male property. The article focuses on how South Africa balances its constitutional mandate in relation to black African lesbians affected by corrective rape. The article argues that it is necessary to define corrective rape as a hate crime and not merely a crime of rape for victims of corrective rape to be adequately protected.
\end{abstract}

Key words: Corrective rape; black African lesbians; South Africa; discrimination

* $\quad$ LLB (Hons) (Malawi), LLM LLD (Western Cape); Imwambene@uwc.ac.za

** LLB LLM (Western Cape); Motjie.wheal@gmail.com. This article is an extract from the one author's LLM thesis titled 'Corrective rape of black African lesbians in South Africa: Realisation or oversight of a constitutional mandate?' (2013). 


\section{Introduction}

The aim of the article is to analyse South Africa's legal response to corrective rape amongst black African lesbians. The article is divided into six sections, the first of which is this introduction. The second section examines the definition of corrective rape and discusses the prevalence of cases of corrective rape in order to determine the extent of the problem. The third section of the article contextualises corrective rape within the constitutional and international law dialogues. The fourth section discusses existing legislation and guidelines available to the judiciary by which to prosecute the perpetrators of (corrective) rape. It also examines those cases which have gone to court in order to assess whether or not South Africa is fulfilling its constitutional mandate in relation to the victims of corrective rape. This is followed by a critical analysis of the criminal justice system in South Africa, focusing on the legislature as well as the judiciary in the fifth part. The last section concludes by arguing that, in order to properly prosecute perpetrators of this offence, corrective rape should be considered a hate crime and not merely a crime of rape.

\section{Corrective rape and its prevalence}

\subsection{Definition of corrective rape}

Before we define corrective rape, it is useful to note that the terms 'corrective' and 'rape' are defined separately. According to the Oxford dictionary, 'corrective' means something which is 'designed to put right something undesirable', 1 whereas the Cambridge dictionary defines it as something which 'intends to improve a situation' or something which 'is intended to cure a medical condition' ${ }^{2}$ Rape, on the other hand, was defined first in terms of the common law until its constitutional validity was challenged in the Masiya case, ${ }^{3}$ where the common law definition was found to be unconstitutional. ${ }^{4}$ The matter was subsequently referred to the Constitutional Court, where the decision of the High Court to develop the common law definition of rape to include 'non-consensual sexual penetration of the male penis into the vagina or anus of another person' was confirmed. ${ }^{5}$ The current definition of rape may be found in the Criminal Law (Sexual Offences and Related Matters) Amendment Act 32 of 2007 (Sexual Offences Act), which states that a person will be guilty of rape if he

Compact Oxford English dictionary for students (2006) 219.

Cambridge advanced learner's dictionary (2003) 273.

S v Masiya (Minister of Justice and Constitutional Development Intervening) 2006 (2) SACR 357.

4 Masiya case (n 3 above) para 60

5 Masiya v Director of Public Prosecutions Pretoria (The State) \& Another 2007 (5) SA 30 (CC) para 93. 
unlawfully and intentionally commits an act of sexual penetration without consent. ${ }^{6}$

A vast number of definitions have been given by different authors for corrective rape. Mieses ${ }^{7}$ refers to corrective rape as sexual punishment by African men towards black African lesbians for being homosexual and violating traditional gender norms. Nklane, ${ }^{8}$ on the other hand, describes it as a practice whereby men rape lesbians in order to 'turn them straight', or to 'cure' them of their sexual orientation. Similarly, the Institute for Security Studies ${ }^{9}$ refers to corrective rape as a non-consensual sexual violation which is directed towards lesbians by persons of the opposite sex with the aim of punishing them and/or curing or correcting their sexual orientation. ActionAid ${ }^{10}$ characterises it as a practice where black African men rape black African lesbians in order to cure them of their lesbianism. ${ }^{11}$ Brownworth, therefore, suggests that corrective rape 'is ... to cure or correct the sexual orientation of lesbians and to force them to act heterosexually and therefore to behave more like women in accordance with the gendered stereotype' ${ }^{12}$

From the above definitions, one can infer that the men who rape these women want to 'put right' something which they find 'undesirable'. As also pointed out by Mehrin, the perpetrators want to teach the victims a lesson by showing them how to be real women, thus forcing them to conform to gender stereotypes stemming from patriarchal male domination which is embedded in culture. ${ }^{13}$ As a result, corrective rape has become an epidemic of violence against

6 Sec 3 Sexual Offences Act. According to ch 1 of the Sexual Offences Act, '[s]exual penetration includes any act which causes penetration to any extent whatsoever by (a) the genital organs of one person into or beyond the genital organs, anus, or mouth of another person; (b) any other part of the body of one person or any object, including any part of the body of an animal, into or beyond the genital organs or anus of another person; or (c) the genital organs of an animal, not or beyond the mouth of another person'.

7 A Mieses 'Gender inequality and corrective rape of women who have sex with women' (2009) http://www.thebody.com/content/art56244.html (accessed 22 August 2012).

8 M Nklane 'Protest against "corrective rape"' (2011) http://www.sowetan live.co.za/news/2011/01/06/protest-against-corrective-rape (accessed 22 March 2011).

9 E Kinama 'Classifying "corrective rape" as a hate crime in South Africa' (2011) http://www.polity.org.za/article/classifying-corrective-rape-as-a-hate-crime-insouth-africa-2011-05-25 (accessed 7 July 2012).

10 A Martin et al Hate crimes: The rise of 'corrective' rape in South Africa' (2009) 3.

11 Corrective rape has also been referred to as 'curative rape' by Bernadette Muthien, director of Engender. Further, the 07-07-07 Campaign has used the term 'hate rape' as cited in NR Bucher 'Law failing lesbians on "corrective" rape' (2009) http://ipsnews.net/news.asp?idnews=48279 (accessed14 March 2011).

12 VA Brownworth 'Op-ed: The other ex-gay "therapy"' (2013) http://www. advocate.com/commentary/2013/07/10/op-ed-other-ex-gay-therapy?page=full (accessed 9 December 2014).

13 SL Mehrin 'Daughters of South Africa' Independent World Report, Issue 6 Spring 2011 http://www.independentworldreport.com/2011/04/daughters-of-southafrica/ (accessed 13 May 2012). 
black African lesbian women, threatening their lives and safety. It is, however, believed that the term 'corrective rape' contributes to the views of the perpetrators. ${ }^{14}$ It is thus maintained by Henderson that the term should be used with great caution as it names an act of violence, using the term of reference of the perpetrators, which leads to the belief that rape can in fact be used to correct or cure lesbians of their sexuality. ${ }^{15}$

\subsection{Prevalence of corrective rape amongst black African lesbians}

There have been numerous incidents of corrective rape over the past years, due to the fact that lesbianism is considered 'unnatural'. Victims are raped with the goal of convincing them that their true orientation in fact is heterosexual. ${ }^{16} \mathrm{~A}$ few of the well-known cases will be discussed below.

\subsection{Cases of corrective rape}

Reliable statistics on incidents of corrective rape are hard to come by, which makes it difficult to determine the true extent of the problem and, in turn, to hold the perpetrators accountable. ${ }^{17}$ This can be attributed to the fact that most incidents go unreported, and those that are reported are not properly identified as homophobic attacks because of the sexual orientation of the victims. ${ }^{18}$ This is verified by a 2004 study which observed that 41 per cent of incidents of rape and sexual abuse targeting lesbian, gay, bisexual, transgender and intersex (LGBTI) persons in Gauteng in fact were reported to the police, while 73 per cent of the respondents contended that they did not report such victimisation as they feared they would not be taken seriously. Another 43 per cent feared abuse by the police and 33 per cent did not want the police to know their sexual orientation. ${ }^{19}$ Similarly, a study by the Forum for the Empowerment of Women found that, out

14 D Robertson 'South African lesbians targeted for rape and violence' (2011) http:// www.voanews.com/english/news/africa/South-African-Lesbians-Targeted-for-Rape -and-Violence-114495619.html (accessed 30 March 2011).

15 As above.

16 R Martin 'Eudy Simelane: Corrective rape, corrective death' (2009) http://global comment.com/2009/eudy-simelane-corrective-rape-corrective-death/ (accessed 29 March 2011). Thokozane Qwabe Ezkheni, stoned and murdered (2007) Ladysmith, KwaZulu-Natal; Khanyisa Hani, stabbed and murdered (2008); Daisy Dube, shot and murdered (2008); Sibongile Mphelo, raped, shot and her vagina cut out (2008); Girly 'S' Gelane Nkosi, stabbed and murdered (2009); and Nontsikeleo (2011), Nyanga, Western Cape. Went to Wynberg Magistrate's Court, Case SHE 79/12. There have been many more victims; the above-mentioned are the tip of the iceberg.

17 N Pillay 'No place for homophobia here' (2011) http://www.iglhrc.org/cgi-bin/ iowa/article/publications/reportsandpublications/1416.html (accessed 30 July 2012)

18 As above.

19 R Davis 'SA's gay hate crimes: An epidemic of violence less recognised' (2012) http://dailymaverick.co.za/article/2012-06-27-sas-gay-hate-crimes-an-epidemic-of -violence-less-recognised (accessed 30 July 2012). 
of 22 lesbians that were raped, 19 failed to report it. ${ }^{20}$ Although this article only focuses on the prevalence of corrective rape of black African lesbians, the authors by no means disregard the seriousness of the abuse and injustices suffered by the LGBTI community as a whole.

It should be noted that, of the cases that will be discussed below, only three have gone to trial successfully. This is despite the fact that there have been a number of cases across South Africa involving the rape, assault and murder of lesbians. ${ }^{21}$ Some of these cases even involve minors. The youngest victim of corrective rape was only 13 years old when the incident occurred. ${ }^{22}$ She was raped in Atteridgeville, Pretoria, after she had declared her sexuality. ${ }^{23}$ In response to the incident, a spokesperson from the Department of Justice and Constitutional Development made a statement in which he stated that '[g]overnment condemns this senseless and cowardly act of criminality' and promised assistance to the girl and her family. ${ }^{24}$ In April 2007, Madoe Mafubedu (16) was raped and repeatedly stabbed to death. ${ }^{25}$ No arrests have been made for the sexual assault and murder of this young woman who lived openly as a lesbian in Soweto, Johannesburg. ${ }^{26}$

Apart from victims who were minors, a young lesbian couple, Sizakele Sigases (34) and Salome Massooa (23), were raped and murdered in Soweto, Johannesburg, on 7 July 2007. ${ }^{27}$ Sizakele was an outreach worker at Positive Women's Network and a well-known gay and women's rights activist. ${ }^{28}$ She lived openly as a lesbian in her community and was subsequently shot six times, her underwear and shoelaces were used to tie her hands and feet and her partner, Salome, was shot in the head. ${ }^{29}$ Prior to her death, Sizakele had complained to friends that she felt threatened in her community due to the fact that she was a lesbian. One week later, the women were

20 IGLHRC Press Release 'South Africa: IGLHRC condemns the killing of 19 year-old Zoliswa Nkonyana in Cape Town and other violence against lesbians' (2006) http://www.iglhrc.org/cgi-bin/iowa/article/pressroom/pressrelease/249.html (accessed 19 August 2012).

21 P Mtetwa 'Trial into murder of lesbian soccer player set for 11-13 Feb at Delmas court' http://www.jwg.org.za/content/view/112/82/ (accessed 30 July 2012).

22 NZ Gay 'Girl, 13, victim of "corrective rape" in South Africa' (2011) http:// www.gaynz.com/articles/publish/3/article_10336.php (accessed 15 August 2011).

23 As above.

24 Staff Reporter 'Thirteen year-old a victim of "corrective rape"' (2011) http:// mg.co.za/article/2011-05-07-thirteenyearold-a-victim-of-corrective-rape (accessed 22 July 2012).

25 Z Muholi 'Mapping our histories: A visual history of black lesbians in postapartheid South Africa' http://zanelemuholi.com/ZM\%20moh_final_230609.pdf (accessed 19 July 2011).

26 R Pithouse 'Only protected on paper' (2011) http://sacsis.org.za/site/article/644.1 (accessed 20 July 2011).

27 Human Rights Watch "'We'll show you you're a woman" - Violence and discrimination against black lesbians and transgender men in South Africa' (2011) 76.

28 Martin et al (n 10 above) 9.

29 Human Rights Watch (n 27 above) 76. 
found murdered next to a dumpsite. ${ }^{30}$ According to a witness, on the fatal night they had suffered homophobic abuse by a crowd of people prior to leaving a local bar. ${ }^{31}$ Three men were detained but subsequently released and the case has since been closed. ${ }^{32}$ After the double murder of these women in 2007, the 07-07-07 Campaign 33 was started to end the targeting of lesbians for violent sexual crimes. ${ }^{34}$ The rape and murder of these women have formed part of a continuing and growing pandemic of targeting black African lesbians in order to forcibly make them conform to what is believed to be normal, namely, being heterosexual.

Another victim, Nosizwe Nomsa Bizana, was gang-raped by five men because of her sexuality. She afterwards succumbed to cryptomeningitis and passed away on 16 December 2007. ${ }^{35}$ Her friend, Luleka Makiwane, who was not ashamed of her sexuality, was raped by her cousin who was HIV positive. ${ }^{36}$ Community activist, Ndumie Funda, fiancée of the late Nosizwe, started a shelter in 2007 for corrective rape victims in the township of Gugulethu near Cape Town. ${ }^{37}$ The initiative is named Luleki Sizwe and provides support for lesbian women in the township, and aims to rescue, feed and nurse survivors of corrective rape. ${ }^{38}$

Zukiswa Gaca was raped first at the age of 15, after which she ran away from the rural village situated in the Eastern Cape, a place she called home, as it was easier than to deal with a community which did not accept her as a lesbian. ${ }^{39}$ She subsequently moved to Khayelitsha ownship where she was confronted by more hate, as 'being a lesbian in Khayelitsha is like you are being treated like an animal, like some kind of an alien or something ${ }^{\prime 40}$ When she was 20 , she met a man in a bar who at first seemed fine with her sexual orientation. ${ }^{41}$ However, when they left the bar, he attacked and raped her and said that he hated lesbians and that he was going to show her that she was not a

30 E Cameron 'The killing of Sistahs' (2007) http://www.atlanticphilanthropies.org/ news/killing-sistahs (accessed 20 August 2012).

31 Martin et al (n 10 above) 9.

32 As above.

33 Named after the murder to mark the date on which the women were murdered.

34 Martin et al (n 10 above) 9.

35 Bucher (n 11 above). See also Mehrin (n 13 above).

36 Mehrin (n 13 above).

37 Bucher (n 11 above).

38 H Haiku 'South Africa: Corrective rape is a hate crime' (2010) http:// globalvoicesonline.org/2010/12/24/south-africa-corrective-rape-is-a-hate-crime/ (accessed 7 April 2011).

39 N Mabuse 'Horror of South Africa's "corrective rape"' (2011) http://edition. cnn.com/2011/10/27/world/wus-sa-rapes/index.html (accessed 3 September 2012).

40 As above.

41 L Hazelton 'Raped for being gay: Scourge of South African sex attacks which men claim will "cure" women of being lesbian' (2011) http://www.dailymail.co.uk/ news/article-2055289/Corrective-rape-South-Africa-women-attcked-cure-lesbians. html (accessed 22 August 2012). 
man, that he was the real man who had all the power over her. ${ }^{42}$ Because of fear, she did not report the first assault which occurred when she was 15, but the attack which occurred in December 2009 she reported to the police. ${ }^{43}$ She accompanied the officer to identify her attacker, upon which he was questioned but subsequently released, and that was where the investigation ended. ${ }^{44}$

Millicent Gaika (30), from the Western Cape, was walking home with friends after a night out. ${ }^{45}$ When they reached her house, they were approached by a man, Andile Ngcoza, whom Millicent was acquainted with, and therefore she told her friends they could walk on. ${ }^{46}$ She was pushed into a shack, after which she was beaten and raped for five hours. ${ }^{47}$ She testified to police that throughout the assault, her attacker repeated the same thing over and over: ${ }^{48}$

You think you're a man, but I'm going to show you you're a woman. I am going to make you pregnant. I am going to kill you.

Her case went to the Wynberg Sexual Offences Court. ${ }^{49}$ Andile was released on R60 bail and fled while he was out. ${ }^{50}$ This led to the case being postponed until his re-arrest, which to date has not happened. ${ }^{5}$ Millicent was taken in by Ndumie Funda who helped her recover from the rape and advocated her case. ${ }^{52}$ Since her attack, Millicent has become an icon in the battle against corrective rape in South Africa.

Shortly afterwards, the body of Noxolo Nogwaza (24), openly lesbian, was found in an alley on 24 April 2011.53 Her head was deformed, eyes out of their sockets, her brain split and her teeth were

42 As above.

43 As above.

44 T Alfred 'The growing trend of "corrective rape" in South Africa' (2011) http:// impunitywatch.com/the-growing-trend-of-\%E2\%80\%9Ccorrective-rape\%E2\%80 \%9D-in-south-africa/ (accessed 30 july 2012).

$45 \mathrm{M}$ Jones 'Five hours of trying to rape a lesbian straight' (2010) http:// news.change.org/stories/five-hours-of-trying-to-rape-a-lesbian-straight (accessed 22 August 2011).

46 As above.

47 L Middleton "'Corrective rape": Fighting a South African scourge' (2011) http:// www.nsvrc.org/news/3746 (accessed 15 November 2011).

48 As above; Jones (n 45 above).

49 J Arnott 'Tabulated report on the incidents of corrective rape in South Africa' (2012) compiled by the Triangle Project, an organisation which deals with issues faced by the LGBTI community. Information received via e-mail from the director of the organisation on 20 July 2012, director@triagle.org.za; Case SHF 132/10, Case 54/94/2010.

50 As above.

51 As above. See also Haiku (n 38 above).

52 Haiku (n 38 above).

53 Human Rights Watch Report (n 27 above) 77. 
scattered around her face. ${ }^{54}$ An empty beer bottle and used condoms were shoved up her genitals and parts of her body were stabbed with glass and the brick used to smash her head was found next to her body. ${ }^{55}$ Her surname, Nogwaza, ironically means 'one who stabs others', but she was the one who became yet another unfortunate victim of corrective rape when a group of men in the Kwa-Thema Township attacked her. ${ }^{56}$

According to a researcher from the LGBTI programme at Human Rights Watch, Noxolo's death was part of a long series of sadistic crimes against lesbians in South Africa. The vicious nature of the assault should serve as a reminder that these attacks are in fact not only premeditated and planned, but that they are committed with impunity. ${ }^{57}$ The case was investigated by the Tsakane police station, ${ }^{58}$ but there have been no arrests made in the matter. In crimes against the LGBTI community, it is literally a matter of life and death for state officials to prosecute the perpetrators and bring them to justice. ${ }^{59}$

Eudy Simelane (31), a well-known Banyana-Banyana soccer player and known lesbian, was gang-raped and murdered on 28 April 2008 in Kwa-Thema, a township near Johannesburg. ${ }^{60}$ She was stabbed more than 20 times, her body found mutilated in an open field. ${ }^{61}$ Four suspects were brought to trial at the Delmas High Court in 2009 of which two were convicted, receiving sentences exceeding 30 years, whilst the other two were acquitted. ${ }^{62}$ This could have been a ground-breaking case to deter further hate crimes directed at lesbians as the perpetrators were convicted. However, attempts to establish the relevance of her sexual orientation to her killers' motives were unsuccessful. ${ }^{63}$ The judge stated that her sexual orientation had no bearing on the case. ${ }^{64}$

54 Ekurhuleni Pride Organising Committee (EPOC) and the Coalition of African Lesbians (CAL) 'Call to action against the brutal rape and murder of South African lesbian Noxolo Nogwaza' (2011) http://www.iglhrc.org/cgi-bin/iowa/article/ takeaction/partners/1376.html (accessed 22 August 2012).

55 As above.

56 E Dlamini 'Lesbian community living in fear after rape' (2011) http:// www.thenewage.co.za/17687-1009-53-Lesbian_community_living_in_fear_after_ rape (accessed 16 September 2011).

57 D Nath 'South Africa: No arrests in lesbian murder case' (2011) http:// www.hrw.org/en/news/2011/05/02/south-africa-no-arrests-lesbian-murder-case/ (accessed 20 May 2011).

58 EPOC (n 55 above).

59 Nath (n 58 above).

60 Human Rights Watch (n 27 above) 76.

61 ILGHRC Press Release 'South-Africa: Statement by Paula Ettelbrinck on the killing of the former Banyana Banyana soccer player Eudy Simelane' (2008) http:// www.iglhrc.org/cgi-bin/iowa/article/pressroom/pressrelease/215.html (accessed 20 August 2012). See also Human Rights Watch (n 27 above) 76.

62 Human Rights Watch Report (n 27 above) 77.

63 As above.

64 Martin et al (n 10 above) 10. 
Another victim was Zoliswa Nkonyana (19), who was brutally murdered in Khayelitsha, Cape Town, on 4 February 2006 when she was stabbed, kicked and beaten to death. She lived her life openly as a lesbian which was the ultimate reason she lost her life when she died metres from her home. ${ }^{65}$ Zoliswa was at a tavern with a friend when an argument broke out centred on the lesbians' use of the ladies toilet, while pretending to be 'tomboys' ${ }^{66}$ They left the tavern and when they separated a group of nine youths caught up with Zoliswa. ${ }^{67}$ The murder of Zoliswa may be seen as a way to communicate to lesbians that they are less than human and that their lives are expendable. ${ }^{68}$ The young men who attacked her were explicit about the fact that they wanted to kill her because she was a lesbian. ${ }^{69}$ This case is a clear example of the intolerance, intimidation and dangers that lesbians face in informal settlements, making them vulnerable and in need of protection. ${ }^{70}$ The case of Zoliswa was one of the longest-running in the country's history as it was postponed 50 times. $^{71}$

The most recent victim of corrective rape is Duduzile ('Dudu') Zozo (26), who was brutally murdered on 30 June 2013 and was found partially naked with a toilet brush shoved up her vagina, a mere 40 feet from her home in a neighbour's yard. ${ }^{72}$ Following the attack on Dudu, the Minster of Women, Children and People with Disabilities strongly condemned the attack and stated: ${ }^{73}$

We strongly condemn and will not tolerate any act of harassment, intimidation or violence against any member of society especially women, children, people with disabilities, the lesbian and gay community.

65 Joint Press Statement (by Social Justice Coalition, Treatment Action Campaign, Free Gender, Triangle Project and Sonke Gender Justice) 'Justice for all! Zoliswa Nknonyana murder trial set to conclude after five years' (2011) http://www.tac. org.za/userfiles/Zoliswa\%20Nkonyana\%20Joint\%20Statement.pdf (accessed 15 November 2011).

66 M de Waal 'We'll make you a "real" woman - even if it kills you' (2011) http:// dailymaverick.co.za/article/2011-12-09-well-make-you-a-real-woman-even-if-itkills-you (accessed on 19 July 2012).

67 As above.

68 Triangle Project and Free Gender Press Release 'Evidence for sentencing in the Zoliswa Nkonyana murder trial' (2012) http://www.facebook.com/notes/triangleproject/triangle-project-and-free-gender-testify-in-zoliswa-nkonyana-murder-trial/ 10150641853203594 (accessed 19 July 2012).

69 N Mkhize et al 'The country we want to live in - Hate crimes and homophobia in the lives of black lesbian South Africans' (2010) Human Sciences Research Council (HSRC Press) 9.

70 Joint Press Statement (n 66 above).

71 M Thamm 'Not just another murder' (2006) http://mg.co.za/article/2006-02-26not-just-another-murder (accessed 19 July 2012).

72 Brownworth (n 12 above).

73 L Xingwana 'SA: Statement by Lulu Xingwana, Minister for Women, Children and People with Disabilities, condemns the brutal rape and murder of Dudu Zozo' (2013) http://www.polity.org.za/article/sa-statement-by-lulu-xingwana-ministerfor-women-children-and-people-with-disabilities-condemns-the-the-brutal-rapeand-murder-of-dudu-zozo-03072013-2013-07-04 (accessed 9 December 2014). 
The trial of Lesley Motleleng (the accused in the matter) was set to begin in May 2014 but was postponed because (according to the magistrate) there were other 'more important cases at the moment'. The trial was to start in October 2014. ${ }^{.4}$ During commemorations for Dudu, it was noted that South Africa was regressing in its constitutional mandate with issues relating to human rights. ${ }^{75}$

\section{Contextualisation of incidents of corrective rape within the constitutional and international law dialogue}

From the above discussion, several conclusions with constitutional implications may be drawn. It is clear that this practice targets black African lesbians in townships. The intersection of race, ethnicity, gender, sexual orientation and class cannot, therefore, be overlooked. In addition, black African lesbians also lack sufficient support systems. ${ }^{76}$ This can be seen from the 2009 report submitted by ActionAid relating to the difference in the number of white lesbians living in fear of sexual assault as opposed to their black counterparts. ${ }^{77}$ Women of all races are inadequately represented in traditionally male-dominated societies as they are underprivileged as women. ${ }^{78}$ In the context of black African lesbians, however, there is an even greater level of disadvantage based on more concrete factors than merely sex. One must, therefore, acknowledge the unique intersectionality by identifying these women as a designated group in need of advancement. Inevitably, this brings the right to equality into play. Section 9 of the South African Constitution provides:

(1) Everyone is equal before the law and has the right to equal protection and benefit of the law.

(2) Equality includes the full and equal enjoyment of all rights and freedoms. To promote the achievement of equality, legislative and other measures designed to protect or advance persons, or categories of persons, disadvantaged by unfair discrimination may be taken.

(3) The state may not unfairly discriminate directly or indirectly against anyone on one or more grounds, including race, gender, sex, pregnancy, marital status, ethnic or social origin, colour, sexual orientation, age, disability, region, conscience, belief, culture, language and birth

74 K Legoete 'A year ago - In memory of Duduzile Zozo' (2014) http://www.irantiorg.co.za/content/Africa_by_country/South_Africa/Duduzile-Zozo-trial/Duduzile_ Zozo_murder.html (accessed 19 December 2014).

75 J Pereira 'In memory of Duduzile Zozo (1987-2013)' (2013) http://www.irantiorg.co.za/content/Africa_by_country/South_Africa/Duduzile-Zozo-trial/Duduzile_ Zozo_murder.html (accessed 19 December 2014).

76 Martin et al (n 10 above) 8.

77 As above.

78 South African Police Service v Solidarity obo Barnard [2014] ZACC 23 para 155. 
(4) No person may unfairly discriminate directly or indirectly against anyone on one or more grounds in terms of subsection (3). National legislation must be enacted to prevent or prohibit unfair discrimination.

(5) Discrimination on one or more of the grounds listed in subsection (3) is unfair, unless it is established that the discrimination is fair.

Race, sex, gender, as well as sexual orientation, are listed grounds upon which discrimination is prohibited. Further legislative and other measures must be taken to protect persons who have been targeted previously by unfair discrimination. The aim is to promote the achievement of equality and freedoms in view of unfair discrimination. ${ }^{79}$

The victims of corrective rape are equal before the law and are protected on the basis of express grounds upon which discrimination is prohibited. However, it is important to note the difference between formal as opposed to substantive equality. Formal equality refers to sameness of treatment whereby individuals in similar circumstances are treated alike. This is in contrast to substantive equality which requires equality of outcome by tolerating disparity of treatment to achieve the said goal. ${ }^{80}$ Therefore, it is clear that the victims of corrective rape need to be afforded substantive equality as opposed to formal equality.

According to Albertyn, patterns of inclusion as well as exclusion in which the behaviour of a particular group is stigmatised have resulted in increased vulnerability to physical violence. ${ }^{81}$ Therefore, victims of corrective rape should be afforded equal protection as they are women, they are black and they are homosexual, which ultimately increases their vulnerability. It is thus logical to assume that further differential treatment will contribute to the perpetuation or promotion of their unfair social characterisation and, consequently, will have a more severe impact on them as they already are vulnerable. ${ }^{82}$ Equal respect for difference is at the heart of equality and largely depends on the protection of minorities. ${ }^{83}$ As it was rightly held in the National Coalition case: ${ }^{84}$

It is easy to say that everyone who is just like 'us' is entitled to equality. Everyone finds it more difficult to say that those who are 'different' from us in some way should have the same equality rights that we enjoy. Yet as soon as we say any ... group is less deserving and unworthy of equal

79 Barnard case (n 80 above) para 135.

80 I Currie \& I de Waal The Bill of Rights handbook (2005) 233

81 C Albertyn 'Substantive equality and transformation in South Africa' (2007) 23 South African Journal on Human Rights 255.

$82 \mathrm{P}$ de Vos \& । Barnard 'Same-sex marriage, civil unions and domestic partnerships in South Africa: Critical reflections on an ongoing saga' (2007) 124 South African Law Journal 799.

83 National Coalition for Gay and Lesbian Equality \& Others v Minister of Home Affairs \& Others 19993 BCLR 280 (C) para 112.

84 National Coalition case (n 85 above) para 22. 
protection and benefit of the law all minorities and all of ... society are demeaned. It is so deceptively simple and so devastatingly injurious to say that those who are handicapped or of a different race, or religion, or colour or sexual orientation are less worthy.

It has been held by the South African Constitutional Court that the concept of sexual orientation as used in section 9(3) should be given a generous interpretation and that it applies to the orientation of all persons who are bi-sexual or transsexual and those persons who are attracted to the same sex. ${ }^{85}$ The only way to recognise sexual orientation as an impermissible ground of discrimination is to base it on a claim to equal protection of the law, which asserts that discrimination on the ground of homosexuality is untenable as sexual orientation should be a matter of indifference, morally as well as constitutionally. ${ }^{86}$ To that end, Sachs J has rightly observed that equality should not be confused with uniformity and that such uniformity may be the enemy of equality as equality does not presuppose the elimination or suppression of difference. ${ }^{87}$

Further, South Africa is committed to the promotion of gender equality and non-discrimination, which is clear from the Preamble of the Promotion of Equality and Unfair Discrimination Act (PEPUDA). ${ }^{88}$ The Act is also clear on its interpretation as it provides that effect must be given to the Constitution in order to protect or advance persons disadvantaged by present discrimination. ${ }^{89}$ This Act specifically acknowledges the necessity of eradicating social and economic inequalities. ${ }^{90}$ Further, it also addresses social structures and practices which encourage or perpetuate unfair discrimination. ${ }^{91}$ According to PEPUDA, all practices, including traditional or customary practices which impair the dignity of women, constitute unfair discrimination. ${ }^{92}$ In addition, it is stated that South Africa is under an international obligation to promote equality and to prevent non-discrimination. ${ }^{93}$

85 National Coalition case, paras 20-21

86 E Cameron 'Sexual orientation and the Constitution: A test case for human rights' (1993) 110 South African Law Journal 464.

87 National Coalition case (n 85 above) para 132

88 The Promotion of Equality and Prevention of Unfair Discrimination Act 4 of 2000 (PEPUDA).

89 Sec 3 PEPUDA.

90 Preamble para 1 PEPUDA

91 Preamble para 2 PEPUDA.

92 Sec 8(d) PEPUDA.

93 Preamble para 4 PEPUDA specifically refers to South Africa's obligations in terms of the United Nations Convention on the Elimination of All Forms of Discrimination Against Women (CEDAW), 1249 UNTS 13, signed 18 December 1979 and the Convention for the Elimination of All Forms of Racial Discrimination (CERD) 660 UNTS 195; GA Res 2106 (XX), Annex, 20 UN GAOR Supp (No 14) UN Doc A/ 6014 (1966). Additional examples of international legislation recognising and protecting the right to equality are the International Covenant on Civil and Political Rights (ICCPR) 999 UNTS 171 and 1057 UNTS 407/[1980] ATS 23 / 6 ILM 368 (1967), the Universal Declaration of Human Rights GA Res 217A (III), UN Doc A/810 71' (1948), the International Covenant on Economic, Social and 
Similarly, at the international level, the United Nations Convention on the Elimination of All Forms of Discrimination Against Women (CEDAW) offers protection to all women and places an obligation upon states to embody the principle of equality of men and women in their national constitutions and to adopt legislative and other measures to prohibit all forms of discrimination against women. ${ }^{94}$ In addition, a duty is placed on states to refrain from practices which discriminate against women and to take measures to eliminate such discrimination by private actors. ${ }^{95}$

Section 9 has been phrased in similar terms to the equality clause of the Canadian Charter. ${ }^{96}$ Both the Canadian Supreme Court and the South African Constitutional Court have interpreted their respective equality clauses as prohibiting all forms of disadvantage, stereotyping as well as prejudicial treatment which have the effect of denying people or groups of people their human dignity. ${ }^{97}$ This ultimately means that any state action which has an adverse impact on disadvantaged groups, such as women or homosexuals, will be subject to close scrutiny and must therefore be shown to be necessary and justified. ${ }^{98}$ The victims of corrective rape are thus equal before the law and should enjoy full protection of their right to equality and non-discrimination.

Another right which is violated by corrective rape is the right to human dignity as guaranteed by section 10 of the South African Constitution. It was held by the South African Constitutional Court that the heart of the equality test lies in whether or not there has been an impairment of the right to dignity as well as the extent to which such impairment has taken place. ${ }^{99}$ It has been held further by the Constitutional Court that discrimination means 'treating people differently in a way which impairs their fundamental dignity as human beings'. ${ }^{100}$ It is clear that when considering the individual cases of the incidents of corrective rape, the inherent dignity of the victims was in fact impaired by the actions of the perpetrators who justify their actions in the name of culture. This is, however, not tolerated in South

Cultural Rights (ICESCR) GA Res 2200A (XXI), 21 UN GAOR Supp (No 16) 49, UN Doc A/6316 (1966); 993 UNTS 3; 6 ILM 368 (1967) as well as the Convention on the Rights of the Child (CRC), UN GA Res 44/25 (1989). These instruments can all be used in efforts to eliminate all forms of discrimination.

94 Arts 2(a) \& (d) CEDAW.

95 Arts 2(d) \& (e) CEDAW.

96 Sec 15(1) of the Canadian Charter of Rights and Freedoms, RSC1985 Appendix II, No 44; see also Part I (secs 1 to 34) of the Constitution Act, 1982, which provides: 'Every individual is equal before and under the law and has the right to the equal protection of the law without discrimination and, in particular, without discrimination based on race, national or ethnic origin, colour, religion, sex, age or mental or physical disability.'

97 C O'Cinneide 'The right to equality: A substantive legal norm or vacuous rhetoric?' (2008) 1 UCL Human Rights Review 87.

98 As above.

99 President of Republic of South Africa v Hugo 1997 (4) SA 1 (CC) para 41.

100 Prinsloo $v$ Van der Linde \& Another 1997 (3) SA 1012 (CC) para 31. 
Africa as the Constitutional Court has held that the right to dignity is not subject to abrogation or subordination to other rights. ${ }^{101}$ Similar to the provisions of section 10 of the Constitution is article 1 of the Universal Declaration of Human Rights (Universal Declaration), which states that all people are born free and equal in dignity as well as rights. The right to dignity is regarded as an important right, even in the international arena, as many international conventions recognise the intrinsic worth of this right.

In addition, section 12 of the Constitution guarantees everyone the right to freedom and security of the person. ${ }^{103}$ In terms of this right, every person has the right to be free from all forms of violence from public or private sources. ${ }^{104}$ In the Carmichele case it was held that the state had a positive duty to protect individuals through laws and structures and that, in the event that it is necessary, it has to take preventative measures where such an individual's life or person is at risk from the criminal conduct of a third party. ${ }^{105}$ This right, therefore, means that everyone has the right to be free from assault and interference from third parties, a right which is infringed by the perpetrators of corrective rape.

Further, this section grants everyone the right to bodily as well as psychological integrity, which includes the right to security and control over one's own body. ${ }^{106}$ This means that everyone has the right to make their own choices with regards to their bodies without interference from other members of society. It is evident from the case studies that the victims were subjected to violence resulting from the criminal conduct of the perpetrators, which inevitably violated their bodily as well as psychological integrity. In a discussion document commissioned by the Deputy Minister of Justice, it was stated that the crime of rape affects all women's sense of safety and their physical integrity as it restricts their mobility and freedom of movement. ${ }^{107}$

The right to life is another right which is protected in the Constitution under section 11, which states that everyone has the right to life. This right is, however, unqualified whereas other jurisdictions and international instruments have qualified the right to

101 RD Glensy 'The right to dignity' (2011) 43 Columbia Human Rights Law Review 99, as cited in S v Makwanyane 1995 (3) SA 391 (CC).

102 See also the ICESCR, Preamble paras $1 \& 2$ and art 13, and the ICCPR, Preamble paras $1 \& 2$ and art 10 .

$103 \mathrm{Sec} 12(1)$ Constitution.

$104 \mathrm{Sec} 12(1)(\mathrm{c})$ Constitution.

105 Carmichele v Minister of Safety and Security \& Another 2001 (4) SA 938 (CC) paras 44-45.

$106 \mathrm{Sec}$ 12(2)(b) Constitution. See also international instruments granting persons the right to physical integrity such as the Universal Declaration in arts $1 \& 3$, the ICESCR in its Preamble, the ICCPR in its Preamble and art 9(1) as well as the CRC in art 19.

107 Discussion document 'Legal aspects of rape in South Africa' (1999) commissioned by the Deputy Minister of Justice 3. 
life by providing that it may not be deprived arbitrarily. ${ }^{108}$ According to O'Regan J, the right to life is antecedent to all other rights in the Constitution as one cannot exercise any of the rights enshrined in the Bill of Rights without life. ${ }^{109}$ It was further held that the right to life goes hand in hand with the right to dignity as, without dignity life is substantially diminished. ${ }^{110}$ Reflecting on the victims of corrective rape, many lost their lives, which is a direct violation of their right to life.

It is thus clear from the above that the fundamental rights of the victims of corrective rape are infringed by the acts of the perpetrators. In support of this, it was held by the Supreme Court of Appeal that judicial officers are aware of the extent to which sexual violence deprives women of their rights to dignity and bodily integrity. ${ }^{111}$ Further, in $S \vee$ Chapman, ${ }^{12}$ it was held that rape in general constitutes a humiliating, degrading as well as brutal invasion of the privacy and dignity of the victim. ${ }^{113}$ The Court further held that rape infringes women's fundamental human rights. ${ }^{114}$ Courts are therefore determined to protect the equality, dignity and freedom of all women and thus no mercy will be shown when these rights are invaded. ${ }^{115}$

The women affected by corrective rape suffer discrimination based merely on the fact they belong to a particular cultural community in addition to the discrimination they suffer as women and as lesbians. ${ }^{116}$

\section{South Africa's response to victims of corrective rape}

\subsection{Legislative framework}

Under South African criminal law, a person may be charged with an

108 Currie \& De Waal (n 82 above) 281. Other jurisdictions include the United States, Canada, Hungary and India and the international instruments referred to are the European Convention for the Protection of Human Rights and Fundamental Freedoms, as amended by Protocols 11 and 14, 4 November 1950, ETS 5, and the ICCPR.

109 Makwanyane case (n 104 above) para 326.

110 Makwanyane case para 327.

111 DPP $\vee$ Prins (Minister of Justice and Constitutional Development \& two amici curiae intervening) (369/12) [2012] 106 ZASCA para 1.

112 Sv Chapman 1997 (3) SA 341 (A).

113 Chapman case (n 115 above) 344.

114 Chapman case 345.

115 Chapman case para 5.

116 This is due to the fact that the perpetrators tacitly claim to act in accordance with their constitutional right to culture as recognised by secs 30 and 31 of the Constitution. This is evident from the reasons and justifications given for corrective rape. As a consequence, there is a clear conflict between the constitutional rights of the perpetrators, used as a 'protective tool' to infringe upon a vast number of constitutional rights of the victims. 
illegal act. ${ }^{117}$ For prosecution to be instituted, it must be shown that a law has been broken, either in terms of statutory law or the common law. ${ }^{118}$ The common law definition of rape was considered in the case of Masiya and was declared unconstitutional. ${ }^{119}$ This means that the crime of rape no longer is deemed to be a common law offence, but a statutory one. The legislative provisions available for prosecuting perpetrators of corrective rape can be found in the Criminal Law (Sexual Offences and Related Matters) Act (Sexual Offences Act) ${ }^{120}$ and the Criminal Procedure Act (CPA).

The Sexual Offences Act provides an amended definition of rape in section 3, which states that a person who unlawfully and intentionally commits an act of sexual penetration on another person without consent is guilty of the offence of rape. To this end, the CPA provides for the imposition of sentencing by a court for the commission of offences, which in this instance would be the crime of rape.

The general principles with regard to sentencing were set out in the Rabie case, where it was held that the punishment should fit the offender, the crime, it must be fair to society and the court must consider the surrounding circumstances of the case. ${ }^{122}$ However, the Criminal Law Amendment Act (Amendment Act) provides for the imposition of minimum sentences for a range of serious crimes. ${ }^{123}$ These crimes are listed in the provisions of the CPA and include rape and murder. ${ }^{124}$ According to the Criminal Law Amendment Act, a first-time offender must be sentenced to a prison term of not less than 15 years. ${ }^{125}$ When imposing sentence, courts must consider and balance certain factors, first established in the 1969 case of Legoa, ${ }^{126}$ namely, the nature and circumstances of the offence, the characteristics of the offender, and the impact of the crime on the community. ${ }^{127}$

Further, it was explained by Cameron J that a criminal trial has two stages, the first being verdict and then sentence. ${ }^{128}$ It was contended that the first stage concerns the guilt or innocence of the accused based on the facts relating to the elements of the offence with which

117 'Chapter 14: Criminal Law and Procedure' (2010) http://section27. org.za.dedi47.cpt1.host-h.net/wp-content/uploads/2010/04/14Manual.pdf (accessed 15 September 2012).

118 As above.

119 Masiya v Director of Public Prosecutions Pretoria (The State) \& Another 2007 (5) SA 30 (CC) para 93. See also ch 22.2 for a discussion of this case.

120 Criminal Law (Sexual Offences and Related Matters) Amendment Act 32 of 2007.

121 Criminal Procedure Act 51 of 1977 (CPA).

122 S v Rabie 1975 (4) SA 855 (A) 826(G).

123 Criminal Law Amendment Act 105 of $1997 \mathrm{sec}$ 51(2).

124 CPA (n 124 above) Schedule 2, part II.

125 Amendment Act sec 52(a)(i).

126 Legoa $v$ S 2002 (4) SA All SA 373 (SCA).

127 S v Zinn 1969 (2) SA 537 (A) 540G.

128 Legoa case (n 129 above) para 15. 
the accused is charged. ${ }^{129}$ The second stage concerns the question of an appropriate sentence where various mitigating as well as aggravating factors may play a role. ${ }^{130}$ This is in accordance with the provisions of PEPUDA: ${ }^{131}$

If it is proved in the prosecution of any offence that unfair discrimination on the grounds of race, gender or disability played a part in the commission of the offence, this must be regarded as an aggravating circumstance for purposes of sentence.

Thus, if prejudice or motive exists in the commission of an offence, it will only play a role in sentencing as an aggravating factor. A mitigating circumstance is youth, as juveniles are sentenced with more leniency than adults. ${ }^{132}$ This is attributed to the fact that they cannot be expected to act with the same measure of responsibility as adults, and their lack of necessary life experience as well as insight which lead them to be prone to thoughtless acts. ${ }^{133}$

For the crime of rape, a mandatory sentence of at least 15 years' imprisonment is proposed by the Amendment Act, but there are various factors which have to be taken into account by the presiding officer when imposing such a sentence. It is now necessary to embark on a discussion surrounding the cases that went to trial in order to determine how the courts have incorporated these legislative provisions when sentencing the perpetrators of corrective rape.

\subsection{Case law on corrective rape against black African lesbians}

The two cases to be discussed are the only ones which were heard and resulted in convictions, despite the fact that there have been numerous cases of rape, assault and murder of lesbians. ${ }^{134}$ Such convictions therefore are the exception.

\subsubsection{Eudy Similane judgment ${ }^{135}$}

The case of Eudy Simelane, an open lesbian activist and soccer star, was heard first in the Springs Magistrate's Court by a magistrate, $\mathrm{Mr} J$ Mokoma. The prosecutor was Mr E Maloba. ${ }^{136}$ Five men

129 As above.

130 As above.

131 Sec 28(1) PEPUDA.

132 PM Bekker et al Criminal procedure handbook (2005) 272.

133 S V Solani 1987 (4) SA 203 (NC) para 220E, as cited in Bekker et al (n 136 above) 272.

134 Mtetwa (n 21 above).

135 This case was not reported and direct references could therefore not be made to the actual judgment. However, there was extensive media coverage on the matter and various interest groups followed the case, its progress as well as the trial religiously.

136 P Gqola 'Eudy Simelane case update 7 Oct 08' (2008) http://pumlagqola. wordpress.com/2008/10/07/eudy-simelane-case-update-7-oct-08/ (accessed 30 March 2011] 
appeared in court from 5 May until 7 October 2008. ${ }^{137}$ After 11 hearings, all charges against accused four, Tsepo Pitja, were withdrawn and he was free to go as there was no evidence which linked him to the crimes. He subsequently became a state witness. ${ }^{138}$ His four co-accused were to appear at the Delmas Court in Mpumalanga from 11 to 13 February 2009 and were remanded until the conclusion of the trial. They faced charges of murder, two counts of robbery and 'other', possibly rape. ${ }^{139}$ On the first day of the trial, the defence attorney for Thato Mphiti, accused four, requested a postponement and justified her request by alleging that the postponement would in fact benefit the state as she needed the additional time to consult with her client and to obtain certain documentation. ${ }^{140}$ An objection was lodged to the application as there was a strong community interest, which was evidenced by the number of people who attended the trial proceedings. ${ }^{141}$ Mavundla J nevertheless held that the delay was not unreasonable and subsequently granted the postponement as it was in the interest of justice and the postponement was until the following day (12 February 2009). ${ }^{142}$

Mphiti pleaded guilty to the count of robbery with aggravating circumstances but not guilty to the count of rape. ${ }^{143} \mathrm{He}$ did, however, plead guilty to assisting his co-accused who attempted to rape Eudy. ${ }^{144}$ The co-accused conversely pleaded not guilty to the charge of robbery with aggravating circumstances. ${ }^{145} \mathrm{~A}$ statement made by Mphiti was read by his defence attorney who outlined the events of the night Eudy was murdered, stating that he and his friends passed Eudy in the early hours of the morning when they decided to rob her. ${ }^{146}$

When discovering that she did not carry any money, it was suggested that she be raped and all of them agreed. ${ }^{147}$ At that point, Eudy had recognised one of them and in fear of being identified, he insisted that she be silenced and passed his knife to Mphiti who panicked and started stabbing her after which she was kicked into a stream. ${ }^{148}$ According to the medical examiner, the wounds were

137 J Henderson 'About the Eudy Enoculate "Styles" Simelane murder case' http:// pda.jwg.org.za/content/view/111/82/ (accessed 30 March 2011)

138 Gqola (n 140 above).

139 As above.

140 D Nath \& J Henderson 'The trial begins ... not' (2009) http://www/jwg.org.za/ content/view/114/82/ (accessed 30 July 2012).

141 As above.

142 As above.

143 J Henderson \& D Nath 'Mphiti pleads guilty' (2009) http://www.jwg.org.za/ content/view/115/82/ (accessed 30 July 2012).

144 As above.

145 As above.

146 As above.

147 As above.

148 As above. 
critical and she could not have survived without immediate medical attention. ${ }^{149}$ After accepting Mphiti's plea, an application was made by the prosecutor to separate his trial from that of the other accused, ${ }^{150}$ which application was granted, and their trial was to commence on 29 July 2009. ${ }^{151}$ The prosecutor, however, failed to raise questions relating to the possibility that prejudice based on the sexual orientation of Eudy was the motivation for the attack. ${ }^{152}$

Mavundla J sentenced Mphiti on 13 February 2009. ${ }^{153}$ He received 18 years' imprisonment on the count of murder, and 15 years on the count of robbery with aggravating circumstances of which 10 years were to run concurrently with the first sentence. ${ }^{154}$ In terms of assisting the other accused with the attempted rape, he received a further 9 years, although it was held that the time already spent in custody should be deducted from the said 9 years, which brought Mphiti's total sentence to 31 years' imprisonment. ${ }^{155}$ Factors given by Mavundla J which were considered in reaching a decision deviating from the mandatory life sentence were, amongst others, the youthfulness of the accused, the fact that Mphiti had been intoxicated at the time the crime was committed as well as his level of education, in addition to the fact that Mphiti suffered from 'fright/fear syndrome'. ${ }^{156}$

The three remaining accused who faced charges of robbery with aggravating circumstances, murder and rape were heard in September 2009. ${ }^{157}$ Magagula and Mahlangu were both acquitted for lack of evidence. ${ }^{158}$ Mokoathleng J found Mvuba guilty of murder, rape and being an accomplice to rape. ${ }^{159}$ Mvuba subsequently received a life sentence. He showed no remorse as he told a reporter: 'Ach, I'm not sorry at all. ${ }^{, 160}$

149 As above.

150 Khumbulanl Magagula, Johannes Mahlangu and Themba Mvubu.

151 Henderson \& Nath (n 147 above).

152 As above.

153 J Henderson 'Mphiti is sentenced' (2009) http://www.jwg.org.za/content/view/ 116/82/ (accessed 30 July 2012).

154 As above.

155 As above.

156 According to the judge, this 'fright/fear syndrome' coupled with the influence of educational level 'impacted on Mphiti's ability to rationalise in a crisis situation', as cited in Henderson (n 157 above).

157 P Mtetwa 'Eudy Simelane murderer gets life imprisonment' (2009) http:// www.womensnet.org.za/news/eudy-simelane-murderer-gets-life-imprisonment (accessed 30 March 2011).

158 As above.

159 As above.

160 B Bearak 'Mixed verdict in South African lesbian's murder trial' New York Times 22 September 2009 http://www.nytimes.com/2009/09/23/world/africa/23safrica. html?_r=2\& (accessed 29 March 2011). 


\subsubsection{Zoliswa Nkonyana judgment}

The Zoliswa case is not one dealing with corrective rape, but has nevertheless been the breakthrough which LGBTI rights groups had been waiting for. Zoliswa was a lesbian who was killed due to her sexual orientation.

Zoliswa's case was heard in the Khayelitsha Magistrate's Court in $2011 .^{161}$ Four of the nine accused were convicted on 7 October 2011 and sentencing was set down for 1 February 2012. ${ }^{162}$ There were originally nine accused, but five were acquitted as the state did not have enough evidence against them. ${ }^{163}$ The magistrate deemed it important to take into account that all the accused were under the age of 18 at the time the offence was committed in 2006 as the sentencing of youthful offenders are difficult to address due to the fact that there are many factors to be considered. ${ }^{164}$ There were three criteria which the magistrate took into consideration: the seriousness and nature of the offence; the interests of the community and the family of the victims; as well as the personal circumstances of the accused. ${ }^{165}$ The magistrate was of the view that sentencing should serve as a deterrent to the accused as well as to the community at large by sending a message that such crimes would not be tolerated and to encourage rehabilitation. ${ }^{166}$

Several factors were considered by the Court before passing sentence. The first factor was the seriousness and nature of the offence. In considering this factor, due consideration was given to the case as proven by the state which dealt with the murder of a young woman whose life was taken away by virtue of her life choices and personal beliefs. ${ }^{167}$ She posed no threat to the accused but yet they acted in a brutal and violent manner which cannot be condoned by the community, nor the court. ${ }^{168} \mathrm{~A}$ representative of the Triangle Project made recommendations with regard to sentencing, that it should reflect the 'extremely brutal nature' of the crime, in addition to

161 Case RCB216/06.

162 J Arnott 'Sentencing of the Zoliswa case: Case number RCB216/06' (unreported). Information received from the director of the Triangle Project who attended the trial proceedings and formulated his own notes. This case is unreported and reliance is thus made on all relevant and important sources and documentation. E-mail received on 20 July 2012 - director@triagle.org.za 682. Accused: Lubabalo Ntlabathi, Sicelo Mase, Luyanda Londzi and Mbulelo Damba.

163 Sabelo Yakiso, Themba Dlephu, Mfundo Kulani, Zolile Kobese and Anele Gwele were acquitted, as mentioned in SAPA '2 acquitted in lesbian murder trial' (2011) http://www.news24.com/SouthAfrica/News/2-acquitted-in-lesbian-murder-trial20110907 (accessed 19 September 2012). See also T Adams ' 18 years won't bring our daughter back' (2012) http://www.iol.co.za/capeargus/18-years-won-t-bringour-daughter-back-1.1226070\#.UAfZMVKyhdg (accessed 19 September 2012).

164 Zoliswa case (n 166 above) 682.

165 Zoliswa case 682-683. These factors are no different to those established in $\mathrm{S} v$ Zinn 1969 (2) SA 537 (A) $540 \mathrm{G}$.

166 Zoliswa case (n 166 above) 683.

167 Zoliswa case 683-684.

168 Zoliswa case 684. 
acknowledging and specifically mentioning that the discrimination based on sexual orientation and gender should be an aggravating factor in sentencing. ${ }^{169}$ During the trial no reference was made as to the motive for the killing of Zoliswa, but it was a necessary factor to consider in sentencing in the view of the Court. ${ }^{170}$ It was held that the 'preceding events to the commission of the offence was a clear indicator as to what the motive was' which, according to the court, was held to be hatred. ${ }^{171}$ Such hatred stemmed from intolerance of her difference and thus the motive was considered as an aggravating factor in sentencing. ${ }^{172}$ The message that the murder of Zoliswa sent was one which blatantly communicated to lesbians that they are less than human and that their lives are expendable. ${ }^{173}$

Secondly, the Court considered the community's and family's interests. It was clear to the Court that the community was outraged by the murder of Zoliswa as the courtroom was over-crowded in addition to the extensive media coverage and attention given to the matter by various interest groups who expressed their discontent. ${ }^{174}$ A report was compiled by the Department of Social Justice regarding the circumstances of the family of the deceased which stated that she was an only child, resulting in an even greater loss to her family. ${ }^{175}$ Further, a report was submitted by the Triangle Project which comprehensively set out the impact which her death had on her girlfriend who had witnessed her murder, as well as giving the Court insight into the problems the LGBTI community faces within their communities and thus shedding some light on the degree of intolerance they suffer as a consequence. ${ }^{176}$

Lastly, the Court also considered the personal circumstances of the accused. The Court came to the conclusion that all four accused came from good homes with loving families and strong support systems, which meant that their families would also suffer a great loss once they were sentenced. ${ }^{177}$ Their families also seemed to show a great degree of empathy for the family of the deceased, as opposed to the accused who were silent on the issue as they showed no remorse for what they had done. ${ }^{178}$ The Court was thus of the opinion that life was about choices and that once a choice is made, the consequences

169 J Henderson \& J Arnott 'Evidence for sentencing in the Zoliswa Nkonyana murder trial: Press statement by the Triangle Project' (2012) http://feministssa.com/2012/ 01/31/evidence-for-sentencing-in-the-zoliswa-nkonyana-murder-trial/ (accessed 19 September 2012).

170 Zoliswa case (n 166 above) 684.

171 Zoliswa case 685.

172 As above.

173 Henderson \& Arnott (n 173 above).

174 Zoliswa case (n 166 above) 685.

175 Zoliswa case 686.

176 As above.

177 Zoliswa case (n 166 above) 687.

178 As above. 
have to be dealt with accordingly. ${ }^{179}$ At the time of the commission of the offence, all four accused were under the age of 18, but this did not retract from the fact that they had to face the consequences of their actions. ${ }^{180}$ All the accused had clean criminal records, but it was discovered that they had had clashes with the law, which were not considered in sentencing as there were no previous convictions. ${ }^{181}$ Further, there were many delays during the trial, ${ }^{182}$ mostly caused by the defence, and one could therefore not punish the accused for such delays, which is why the court considered it in their favour. ${ }^{183}$

In sentencing, the magistrate was of the view that sentencing should not only be considered as a form of punishment, but rather as something which should instil a sense of retribution and rehabilitation in addition to serving as a deterrent. ${ }^{184}$ Retribution, according to the Court, was not to be confused with revenge. ${ }^{185}$ Zoliswa would never be returned to her family and the accused should pay the price for their actions in that regard in order to restore some sort of justice to her family as well as to the community at large. ${ }^{186}$ In terms of rehabilitation, it was contended that in order for it to be effective, there should be a realisation of the wrongfulness of the actions; there should be acceptance of responsibility for the actions as well as a willingness to make right the wrongs caused. ${ }^{187}$ In the view of the Court, acceptance of responsibility and acknowledgment of wrongfulness were key elements in mitigation of sentence, which seemed to be absent in this case as none of the accused showed any remorse and thus re-offending could not be excluded. ${ }^{188}$ In so far as deterrence was concerned, the Court was of the view that it should not only be directed at the accused, but sentencing should also send a clear message to 'would-be' offenders that violent crime would not be tolerated by the courts. ${ }^{189}$

After considering a potential mitigating factor, the Court moved on to discuss the aggravating factors and took cognisance of the fact that we live in a diverse society which requires a greater degree of tolerance. ${ }^{190}$ When constitutional rights clash, it is up to the court to

\footnotetext{
179 As above.

180 Zoliswa case (n 166 above) 688.

181 As above.

182 Zoliswa case (n 166 above) 689. The accused pleaded to the charge on 27 August 2008. The conviction took place three years later on 7 October 2011 and sentencing only took place on 1 February 2012. The case of Zoliswa was therefore one of the longest-running in the country's history as it was postponed 50 times, as cited in Thamm (n 72 above).

183 Zoliswa case (n 166 above) 689.

184 Zoliswa case 690.

185 As above.

186 Zoliswa case (n 166 above) 691

187 As above.

188 Zoliswa case (n 166 above) 691-692.

189 Zoliswa case 691.

190 Zoliswa case 692.
} 
weigh up conflicting rights in order to reach a determination. ${ }^{191}$ The deceased exercised her right to live openly as a lesbian in her community, which was a clear and conscious choice that she made, a choice which the accused quite clearly did not agree with. ${ }^{192}$ Personal opinion and free choice are other constitutional rights which all persons are entitled to, but having entitlement to one's opinion and acting out based on that opinion in a brutal and public way thus expressing clear intolerance were not acceptable to the Court. ${ }^{193}$ The Court held: 194

$[T]$ he court has a duty to enforce the ideology that violent intolerance of difference, whether it be based on race, whether it be based on sex, whether it be based on religion, [whether it be based on sexual orientation], ${ }^{195}$ it will not go unpunished and it will not go rewarded.

In light of all the factors which were taken into consideration, imprisonment was the only appropriate sentence in the view of the Court. ${ }^{196}$ That the accused were all first-time offenders in addition to having the support of their families were considered. This was, however, weighed against the aggravating factors surrounding the case. ${ }^{197}$ Sentencing was pronounced: 'a term of eighteen (18) years' imprisonment of which four (4) years is suspended for a period of five (5) years' on the condition that they were not convicted of murder during the period of suspension. ${ }^{198}$

\section{Analysis of South Africa's response}

\subsection{Law enforcement}

When an offence is committed, it is the investigated by law enforcement (the police). The aim of such an investigation is to collect evidence which will be presented in court as well as to record the incidents in order to create reliable statistics with the aim of establishing the true extent of the problem. Currently, corrective rape is not recognised as a separate crime category in South Africa, which is one of the reasons why reliable statistics are hard to come by as no distinction is made between rape and corrective rape. Thus, the incidents that are reported will merely be recorded as rape despite the fact that there are in fact distinct differences between these two crimes.

\footnotetext{
191 As above.

192 As above.

193 As above.

194 Zoliswa case (n 166 above) 692.

195 Our emphasis.

196 Zoliswa case 693.

197 Zoliswa case 695.

198 Zoliswa case 693.
} 
In addition, it has been shown that the reason reliable statistics of corrective rape incidents are hard to come by is the fact that the majority of incidents are either unreported or misidentified in that the sexual orientation of the victims is not taken into account. In support of this, a study conducted by ActionAid showed that 66 per cent of women failed to report their attacks for the fear of not being taken seriously. Further, 25 per cent feared exposing their sexual orientation to the police as they were fearful that they would suffer added abuse. ${ }^{199}$ These fears are justified as they emanate from the fact that when these women are raped, the perpetrators believe that they deserved it as they were shown how to be real women. ${ }^{200}$

When one takes into account that these incidents occur mainly in townships due to the cultural attitudes and views of the perpetrators, it is understandable that the victims are fearful to report these incidents as it is reasonable to expect that they might be subjected to further victimisation. It was also shown that the incidents which were reported were not followed up and thus could not be brought before the courts. This can be corroborated by the case studies which were discussed, as the perpetrators involved in the attack against Sizakele Sigases and Salome Massooa were initially detained but subsequently released. Similarly, Zukiswa Gaca was attacked on two occasions and accompanied the investigating officer to identify her attacker, but he was released. Moreover, the man who raped Millicent Gaika received a ridiculously low bail after which he fled and was never found again. These are the messages that the victims of corrective rape receive, serving as an additional deterrent to reporting such incidents as they fear they will not be taken seriously.

\subsection{Legislature}

The legislative provisions available and utilised to prosecute the perpetrators of corrective rape are aimed and directed at the crime of rape and provide guidelines along with mandatory sentencing periods. Corrective rape is, however, not the same as 'mere' rape in that it is committed based on prejudice and intolerance. It has been shown that motive only becomes relevant during sentencing. This was also evident in the Zoliswa judgment, where it was held that motive is not an element to be proven during criminal trials and it therefore very often leads to such trials being concluded without a motive ever being established. This is due to the fact that 'it never froms part of the body of evidence and often people are left dumbfounded as to why a praticular crime is committed' ${ }^{201}$ It was subsequently held that motive was to be considered an aggravating factor in sentencing which means that the motive was not a factor which was considered or one which carried any weight in terms of conviction. If,

199 Martin et al (n 10 above) 13.

200 As above.

201 Zoliswa case (n 166 above) 684-685. 
hypothetically speaking, the accused had been acquitted, the motive for her killing would never have been established.

The definition of the statutory offence of rape and provisions on mandatory sentencing are set out in legislation. However, no legislative definition or mandatory sentencing exists for corrective rape. This is supported by section 28 of PEPUDA, read together with section 3, which confirms that where unfair discrimination played a role in the commission of the offence, it should contribute to the imposition of a harsher sentence. It is noted by the authors that no specific mention is made of sexual orientation in the provisions of the Act, which can or may be attributed to a legislative oversight at the time of its promulgation. As mentioned before, section 3 clearly states that when interpreting the Act, one must do so to give effect to the Constitution and other measures which were designed to protect or advance persons disadvantaged by past as well as present unfair discrimination. It is thus clear that, even though sexual orientation was not specifically mentioned, it should be included as a ground of unfair discrimination.

In addition, South Africa's failure to fulfil its constitutional mandate in relation to victims of corrective rape also is due to the definition of corrective rape. If corrective rape were to be considered a hate crime and not merely as a crime of rape, then it would be easier to successfully prosecute perpetrators of this offence. The term 'hate crime' comes with differing perspectives and includes various definitions within and between countries, but most of the qualities within these definitions tend to overlap. ${ }^{202} \mathrm{~A}$ hate crime is an act which constitutes a criminal offence and is motivated in whole or part by prejudice or hate. ${ }^{203}$ There are a range of crimes that could be considered 'hate crimes', such as damage to property, murder, arson, intimidation, assault and rape. ${ }^{204}$ Hate crimes also refer to ${ }^{205}$

actions against a person based on their race, ethnicity, sexual orientation, religion or political convictions or gender that intends to do harm or intimidate the person ...

Hate crimes thus generally are seen as acts of prejudice or message crimes and are mostly violent in nature. ${ }^{206}$ Classifying corrective rape merely as a criminal act ignores the inherent prejudice involved in the

202 B Harris 'Arranging prejudice: Exploring hate crime in post-apartheid South Africa' Race and Citizenship in Transition Series, 2004, http://www.csvr.org.za/wits/ papers/paprctp1.htm\#series (accessed 14 November 2011).

203 'Hate crimes in South Africa' background paper for the Hate Crimes Working Group 1.

204 As above.

205 'Hate crimes against gay and lesbian people in Gauteng: Prevalence, consequences and contributing factors', research Initiative of the Joint Working Group conducted by OUT LGBT Well-being in collaboration with the UNISA Centre for Applied Psychology 1.

206 Harris (n 208 above). 
perpetration of the crime itself. ${ }^{207}$ Hate crimes by nature cause greater harm than ordinary crimes because they increase the vulnerability of the victims as they are unable to change the characteristic which made them a target. ${ }^{208}$ As a result it is of the utmost importance to recognise corrective rape as a hate crime as the victims are unable to change their sexual orientation.

The Convention on the Elimination of All Forms of Racial Discrimination (CERD) defines hateful activities as all those which are based on ideas or theories of superiority of one race or group of one colour or ethnic origin, which justify or promote racial hatred and discrimination. ${ }^{209}$ These definitions both describe crimes that are motivated by prejudice and therefore the definition of a 'hate crime' could be described as 'motive-driven'. ${ }^{210}$

For example, xenophobia swept across South Africa in 2008 and 2015 when foreign nationals were attacked in over 130 locations in various parts of the country. ${ }^{211}$ Many were killed, hundreds injured and over 100000 displaced. ${ }^{212}$ This phenomenon is defined as an attack on foreign nationals which is seen as a violent crime, not only in South Africa but also abroad, as the Special Rapporteur ${ }^{213}$ on the Human Rights of Migrants stated that indeed xenophobic violence is a global problem that has been extensively documented in many countries, including in South Africa'. ${ }^{214}$ After these xenophobic attacks, calls were made to criminalise the attacks against foreigners as hate crimes. ${ }^{215}$

The Special Rapporteur's report made important recommendations to South Africa of which many have been previously advanced by the South African Human Rights Commission, the Consortium for Refugees and Migrants in South Africa, the African Centre for Migration and Society, Lawyers for Human Rights as well as Human Rights First. ${ }^{216}$ The Special Rapporteur called on authorities to 217

207 Consortium for Refugees and Migrants in South Africa (CORMSA) 'Hate crimes in South Africa - A background paper for the Hate Crimes Working Group. (2011) http://www.cormsa.org.za/wp-content/uploads/2010/07/hate-crimes-workinggroup-background-paper.pdf (accessed 19 December 2014).

208 Hate crime laws: A practical guide (2009) published by the OSCE Office for Democratic Institutions and Human Rights (ODIHR) 20.

209 Art 4 CERD.

210 Harris (n 208 above).

211 P LeGendre 'UN expert highlights xenophobia in South Africa, calls for hate crime legislation' (2011) http://www.humanrightsfirst.org/2011/06/03/u-n-expert-high lights-xenophobia-in-south-africa/ (accessed 7 April 2011).

212 As above.

213 Jorge Bustamante, Special Rapporteur on the Human Rights of Migrants.

214 LeGendre (n 218 above).

215 Mkhize et al ( $\mathrm{n} 70$ above) 17.

216 LeGendre (n 218 above).

217 As above. 
[m]ake any act of violence against individuals or property on the basis of a person's race, nationality, religion, ethnicity, sexual orientation or gender identity ('hate crime') an aggravating circumstance.

Hate crimes, therefore, are essentially defined as an assault against all members of stigmatised as well as marginalised groups and communities, embedded in the structural and cultural context with which those groups interact. ${ }^{218}$ The International Lesbian, Gay, Bisexual, Trans and Intersex Association (ILGA) reported that hate crimes based on sexual orientation were only considered an aggravating factor in 17 countries, of which South Africa is not one. ${ }^{219}$ This is alarming as South Africa has a history of gross human rights violations and should thus have greater protection in place to combat these very serious issues.

When considering the definition of hate crimes, the crux and decisive factor which set it apart from other ordinary crimes is the motive behind the commission of the offence. As was rightly pointed out, hate crimes can be defined as 'actions against a person based on their race, ethnicity, sexual orientation, religion or political convictions or gender that intends to do harm or intimidate the person'. ${ }^{220}$

Corrective rape quite clearly conforms to this definition as it is committed against black African lesbians based on their sexual orientation, which is intended to ultimately harm them and to send a message to other non-conforming lesbians in the hope that they will see the error of their ways and turn straight. This crime is motivated by prejudice, as the court in the Zoliswa judgment rightly pointed out the fact that the motive was based on the intolerance of her difference, the fact that she was a lesbian.

There are two conflicting schools of thought on how to deal with hate crimes in the criminal justice system, as some advocate for evidence of hate to be presented during the trial in order to prove it as a hate crime, whereas others contend that evidence relating to hate should only be led as an aggravating factor during sentencing. ${ }^{221}$ Hatred may, however, only be discussed during trial proceedings if and when it has been classified as a crime category. Consequently, in

218 'An exploration of hate crime and homophobia in Pietermaritzburg, KwaZuluNatal' research report commissioned by the Gay and Lesbian Network 13.

219 D Ottosson 'State-sponsored homophobia: A world survey of laws prohibiting same-sex activity between consenting adults' (2010) ILGA Report 48.

220 'Hate crimes against gay and lesbian people in Gauteng' (n 209 above) 1.

221 R Davis 'SA's gay hate crimes: An epidemic of violence less recognised' (2012) http://dailymaverick.co.za/article/2012-06-27-sas-gay-hate-crimes-an-epidemicof-violence-less-recognised (accessed 30 July 2012). These approaches can also be looked at within the two international models of hate crime legislation, as noted by D Breen \& J Nel 'South Africa - A home for all?' (2011) SA Crime Quarterly No 38: the 'hostility model' and the 'discriminatory selection model'. The hostility model regards crimes as crimes motivated by hatred or hostitlity based on factors such as race, sexual orientation or nationality. The discriminatory selection model takes into account the perpetrator's deliberate selection of a victim based on race and other protected characteristics that would constitute hate crime. 
the South African justice system, it may only be brought up during sentencing to serve as an aggravating factor for sentencing. Therefore, in accordance with this understanding, the second approach was followed in the Zoliswa case when the four men were convicted in 2012 by Magistrate Whatten, who concluded that she had been murdered because she exercised her right to live openly as a lesbian and that hatred and intolerance which drove the crime were aggravating sentencing factors. ${ }^{222}$ This was a breakthrough for LGBTI rights group Triangle Project as the judgment set an important precedent in the South African criminal justice system. ${ }^{223}$

The Zoliswa case was the first case in which evidence relating to hatred and prejudice was introduced in order to argue for a harsher sentence on the accused. It is clear from the Zoliswa judgment that motive is not an element of a crime, which is why it was held that motive was an aggravating factor which was considered in sentencing only. The case, therefore, was also illustrative of the two-stage approach as per Cameron J in the Legoa judgment.

Lastly, the manner in which the cases that landed before court were handled shows that there is a misrecognition of the conflict between the right to culture of the perpetrators and the right to equality of the victims. First and foremost, reflecting on the Eudy judgment, her sexual orientation was ruled out early by the court as a reason and motive for her murder. ${ }^{224}$ It was, however, contended by Phumi Mtetwa $^{225}$ that people in the township knew Eudy as a soccer player in the community and they could tell from her appearance that she was 'butch'. ${ }^{226}$ She thus concluded by saying that people are killed because of who they are. ${ }^{227}$ According to Mbaru, a co-ordinator of IGLHRC's Africa Programme, the level of homophobia in the courtroom was appalling as Mokgothleng J objected to the use of the word 'lesbian' in his court. ${ }^{228}$ It is contended by IGLHRC that homophobia is the factor which prevented the judge from fully acknowledging the role of Eudy's sexual orientation as a motive for the crime. ${ }^{229}$ The partial conviction has thus sent a message that the brutal rape and murders of lesbians may continue with impunity, an antithesis to building a culture of good governance in South Africa. 230 If the motive for her killing had been established, the case would have

222 Davis (n 229 above).

223 As above.

224 D Smith 'Life for man in rape and killing of lesbian South African footballer' (2009) http://www.guardian.co.uk/world/2009/sep/22/eudy-simelane-gangrape-andmurder (accessed 20 May 2012).

225 Executive Director of the Lesbian and Gay Equality Project (LGEP).

226 Smith (n 232 above).

227 As above.

228 S Tobias 'Scant justice in South African murder case; Courts must value lesbian lives!' (2009) http://www.iglhrc.org/cgi-bin/iowa/article/pressroom/pressrelease/ 976.html (accessed 30 July 2012).

229 As above.

230 As above. 
been a breakthrough in terms of the continuous battle against corrective rape. Future perpetrators might have been deterred to some extent as it would have sent a message that crimes committed based on hate and intolerance would not be condoned.

The above discussion leads us to draw one very important inference: that the judiciary missed an opportunity to resolve the conflict between the right to culture and the right to equality in the context of corrective rape. This is supported by a Periodic Review of the Human Rights Council, in which the CEDAW Committee 231 expressed concern relating to harmful cultural practices. ${ }^{232}$ South Africa was urged to implement a strategy to modify or eliminate such harmful practices and stereotypes which discriminate against women. ${ }^{23}$ It was also quite evident in the Eudy judgment that the judge was not attuned to the effects of prejudice or discrimination which motivated the offence and therefore the motivation for her attack carried no weight.

In addition, it has been proved that there is an inherent conflict between the right to culture of the perpetrators and the constitutionally-protected rights of the victims. The courts have also clearly set out how this conflict is to be resolved. It should thus be noted that in neither of the two judgments relating to corrective rape was this conflict specifically addressed or resolved. The importance of recognising this conflict lies in the fact that one needs to take into account that both the perpetrators and the victims are protected by the Bill of Rights and that one cannot disregard the importance of their rights.

This is also in line with Shue's general theory on the duties of the state with regard to its positive responsibilities for eradicating violence against women. ${ }^{234}$ His formulation consists of three parts, of which the first is the duty on the state not to violate the right being scrutinised which is, in this case, the right to culture. ${ }^{235}$ Second is the duty on the state to protect against the violation of the right and, last, a duty to aid those whose rights have been violated. ${ }^{236}$ To counteract these duties, it is important to note the general as well as internal limitations placed on the right to culture in terms of the Constitution itself. $^{237}$ In support of this it was held in the dissenting judgment of

231 CEDAW (n 96 above).

232 Human Rights Council, Working Group on the Universal Periodic Review. 13th session, Geneva, Switzerland, 21 May-4 June 2012. Compilation prepared by the Office of the High Commission for Human Rights in accordance with para 5 of the annex to Human Rights Council Resolution 16/21, South Africa, UN Doc A/HRC/ WG.6/13/ZAF/2 (23 March 2012) para 17.

233 As above.

234 H Combrinck 'Positive state duties to protect women from violence: Recent South African developments' (1998) 20 Human Rights Quarterly 668.

235 Combrinck (n 243 above), as cited by H Shue Basic rights: Subsistence, affluence and US foreign policy (1980) 52.

236 As above.

237 As discussed in sec 3.3 (see discussion on secs $30,31 \& 36$ of the Constitution). 
the Bhe case that, when the right to culture infringes on the rights of others, it should be developed to be in line with the Constitution. Moreover, because Shue proposes that every basic right assumes the three mentioned duties, those duties should then also be applied to the rights of the victims which have been violated. Hence, there is a duty on the state to avoid violating the rights in question, namely, the rights to equality, dignity, freedom as well as life. Further, there is a duty to protect the victims from the violation of their rights and they must aid those whose rights have been violated.

In addition, the Constitution has a built-in supremacy clause, stating that the Constitution is the supreme law of the Republic and, consequently, any law or conduct inconsistent with it is invalid. 238 This section creates a duty to fulfil the rights as set out in the provisions of the Bill of Rights. The right to culture as well as the rights to equality, dignity, freedom and life are protected in the Bill of Rights. This gives rise to an inherent conflict. In the event that such a conflict arises, one must weigh up the conflicting interests of the parties having due regard to the internal as well as general limitations. Thus, the requirement to develop customary law to bring it in line with the Constitution was overlooked in the judgments discussed. As a consequence, the court erred when it failed to identify the inherent clash between these competing rights.

However, it was noted in the Zoliswa judgment that, although everyone is entitled to their opinion, one may not act based on such opinion in a brutal manner professing your intolerance of the opinion of another. ${ }^{239}$ The fact that the Court merely acknowledged the existence of a potential clash but failed to subsequently address it led to the issue remaining unanswered.

\section{Conclusion}

We discussed and analysed South Africa's legal response to victims of corrective rape in order to assess whether the country fulfils its constitutional mandate of protecting these victims. We showed that, in general, the South African justice system ${ }^{240}$ has failed the victims of corrective rape in more than one regard. This inference is drawn for a number of reasons. First, the number of corrective rapes do not correspond with the number of cases that have gone to court for prosecution, as shown above. There have only been two cases heard by the courts, both of which are unreported. Further, only one case can be properly analysed to ascertain how the court has interpreted the infringement and whether justice has been restored.

$238 \operatorname{Sec} 2$ Constitution.

239 Zoliswa case (n 166 above) 692.

240 For purposes of this discussion, the justice system comprises of law enforcement, the legislature as well as the judiciary. 
Second, the courts missed an opportunity to resolve the conflict between the right to culture and the right to equality in the context of corrective rape since there is an inherent conflict between these rights For example, it was evident in the Eudy judgment that the judge was not attuned to the effects of prejudice or discrimination which motivated the offence leading to her death and, therefore, the motivation for her attack carried no weight.

Lastly and, most importantly, South Africa's failure to fulfil its constitutional mandate with regard to corrective rape also lies with the definition of corrective rape. The legislative provisions available and utilised to prosecute perpetrators of corrective rape are aimed and directed at the crime of rape and provide guidelines for mandatory sentencing periods accordingly. Corrective rape, however, is not the same as 'mere' rape in that it is committed because of prejudice and intolerance.

We therefore conclude by reiterating what others have observed: that in order to properly prosecute perpetrators of this offence, corrective rape should be considered a hate crime and not merely a crime of rape. 